\title{
KARST LANDFORMS WITHIN NOCTIS LABYRINTHUS, MARS
}

\author{
KRAŠKE RELIEFNE OBLIKE NA OBMOČJU NOCTIS \\ LABYRINTHUS, MARS
}

\author{
Davide BAIONI $^{1}$, Mario TRAMONTANA ${ }^{1} \&$ Nadja ZUPAN HAJNA ${ }^{2}$
}

\begin{abstract}
UDC 551.435.8:523.43

Davide Baioni, Mario Tramontana \& Nadja Zupan Hajna: Karst landforms within Noctis Labyrinthus, Mars

Noctis Labyrinthus is an intricate system of Late Hesperian and Early Amazonian linear troughs and rounded pits connecting the Tharsis volcanic rise and western Valles Marineris next to Martian equator. This study was focused on three light-toned deposits (LTDs) located within a trough located in the western part of Noctis Labyrinthus, centered at $-6.8^{\circ} \mathrm{N}$, $261.1^{\circ} \mathrm{E}$, approximately $60 \times 50 \mathrm{~km}$ in dimension and with a depth of $5 \mathrm{~km}$ below the adjacent plateau. These LTDs located on the floor in the central region of this trough display spectral signature of gypsum and are characterised by the widespread presence of shallow depression morphologies. We performed a morphologic and morphometric analysis of the surfaces of these LTDs through an integrated study of images available through the Reconnaissance Mars Orbiter High-Resolution Imaging Science Experiment with the aim to describe, for the first time, these landforms, and to discuss their possible origins and lithological and paleo-climatic significance. Analysis, on the basis of the characteristics of the investigated landforms and the similarities of features on Earth and Mars, and after discarding other possible origins, revealed that the examined Martian landforms have karst origin. The landform features appear to reflect water-related processes, probably due to ice melting formed during periods of ice-snow-rich deposition from the atmosphere as the result of changes in the obliquity of Mars, which could have driven the processes of dissolution or collapse on the evaporite rock. Thus, the observed karst landforms suggest a climate change and the presence of liquid water due to ice melting during the Late Amazonian age.

Key words: karst, gypsum, shallow depressions, climate change, Noctis Labyrinthus, Mars.
\end{abstract}

Izvleček UDK 551.435.8:523.43

Davide Baioni, Mario Tramontana \& Nadja Zupan Hajna: Kraške reliefne oblike na območju Noctis Labyrinthus, Mars Noctis Labyrinthus je zapleten sistem pozno hesperijskih in zgodnje amazonijskih linearnih jarkov in krožnih globeli, ki povezuje vulkanski plato Tharsis in zahodni del Valles Marinerisa ob Marsovem ekvatorju. Ta študija je bila osredotočena na tri svetlo tonirane usedline (LTDs), ki se nahajajo $\mathrm{v}$ dnu jarka v zahodnem delu Noctis Labyrinthusa, s središčem območja na $-6.8^{\circ} \mathrm{N}, 261.1^{\circ} \mathrm{E}$, velikega približno $60 \times 50 \mathrm{~km}$ in globino $5 \mathrm{~km}$ pod površjem bližnjega platoja. Te LTDs kamnine, ki se nahajajo na tleh v osrednjem območju tega jarka, izkazujejo spektralni zapis sadre, na njih je značilna prisotnost številnih plitvih depresij. Izvedli smo morfološke in morfometrične analize površin teh LTDs kamnin in to preko celostne študije slik visoke ločljivosti, ki so na voljo prek Marsovega Orbiterja (Reconnaissance Mars Orbiter High-Resolution Imaging Science Experiment) $\mathrm{z}$ namenom, da prvič opišemo ta površja, da razpravljamo o njihovem morebitnem izvoru ter njihovemu litološkemu in paleoklimatskemu pomenu. Analiza je na podlagi značilnosti preiskovanih reliefnih oblik in podobnosti z reliefnimi oblikami na Zemlji in Marsu ter zavržku drugih možnih izvorov pokazala, da so preiskane reliefne oblike na Marsu kraškega izvora. Zdi se, da preučevane oblike površja odražajo procese povezane $\mathrm{z}$ vodo, ki je najbrž nastajala zaradi taljenja ledu, tvorjenega v obdobjih bogatega odlaganja ledeno-snežnih plasti iz atmosfere, kot posledica sprememb v nagnjenosti osi Marsa, kar bi lahko povzročilo procese raztapljanja ali razpadanja na evaporitnih kamninah. Posledično opazovane kraške reliefne oblike kažejo na podnebne spremembe in prisotnost tekoče vode zaradi taljenja ledu $\mathrm{v}$ času poznega amazonija.

Ključne besede: kras, sadra, plitve depresije, podnebne spremembe, Noctis Labyrinthus, Mars.

\footnotetext{
${ }^{1}$ Planetary Geology Research Group, Dipartimento di Scienze Pure e Applicate (DISPeA), Università degli Studi di Urbino, Campus Scientifico “E. Mattei”, 61029 Urbino (PU). Tel. and Fax: 0722/304268, e-mail: davide.baioni@uniurb.it

${ }^{2}$ Karst Research Institute ZRC SAZU, Titov trg 2, 6230 Postojna, Slovenia, e-mail: zupan@zrc-sazu.si
}

Received/Prejeto: 22.09.2016 


\section{INTRODUCTION}

The existence of karst landforms on Mars has been hypothesised since high-resolution Viking Orbiter images first became available. Schaefer (1990) suggested that the "thumbprint" terrains noted by Guest et al. (1977) on the northern plains of Mars were formed by differential solutions of large carbonate deposits in low-lying areas. Karst-like topographies and karst processes have been hypothesised to be present in many regions of the Martian surface (Costard \& Kargel 1995; Kargel et al. 2004). The presence of soluble evaporite minerals on Mars supports the possible development of evaporite karst similar to that on Earth (Stafford \& Boston 2005) and the development of karstic terrains with associated caves (Boston 2004; Johnston et al. 2006). This possibility was confirmed by data from the OMEGA instrument on Mars Express (Bibring et al. 2006), the Compact Reconnaissance Imaging Spectrometer for Mars instrument (Murchie et al. 2007) on the Mars Reconnaissance Orbiter (MRO), and the Mars Exploration Rovers.

Recent studies, based on new high-resolution images, demonstrate the presence of karst landforms and processes in Martian evaporite deposits (Baioni et al. 2009; Baioni \& Wezel 2010; Grindrod \& Balme 2010; Baioni et al. 2011; Jackson et al. 2011) and highlight the usefulness of karst landforms as lithological and stratigraphic markers (Baioni \& Sgavetti 2013).
Noctis Labyrinthus (below indicates as NL) (Fig.1) is an intricate system of Late Hesperian and early Amazonian linear troughs and rounded pits connecting the Tharsis volcanic rise and western Valles Marineris (Tanaka et al. 2014; Rodriguez et al. 2016). The study was focused on a trough located in the western part of $\mathrm{NL}$ (Figs. $1 \mathrm{~A}-1 \mathrm{~B}$ ), centered at $-6.8^{\circ} \mathrm{N}, 261.1^{\circ} \mathrm{E}$, approximately $60 \times 50 \mathrm{~km}$ in dimension and with a depth of 5 $\mathrm{km}$ below the adjacent plateau (Weitz et al. 2013).

On the floor in the central region of this trough was identified the presence of light toned deposits (below indicate as LTDs) that display spectral signature of gypsum and are characterised by the widespread presence of shallow depression morphologies of unknown origin, which display different shapes and sizes.

The goals of this study were to describe, for the first time, the landforms in LTDs located within this trought in Noctis Labyrinthus, and to discuss their possible origins and lithological and paleo-climatic significance.
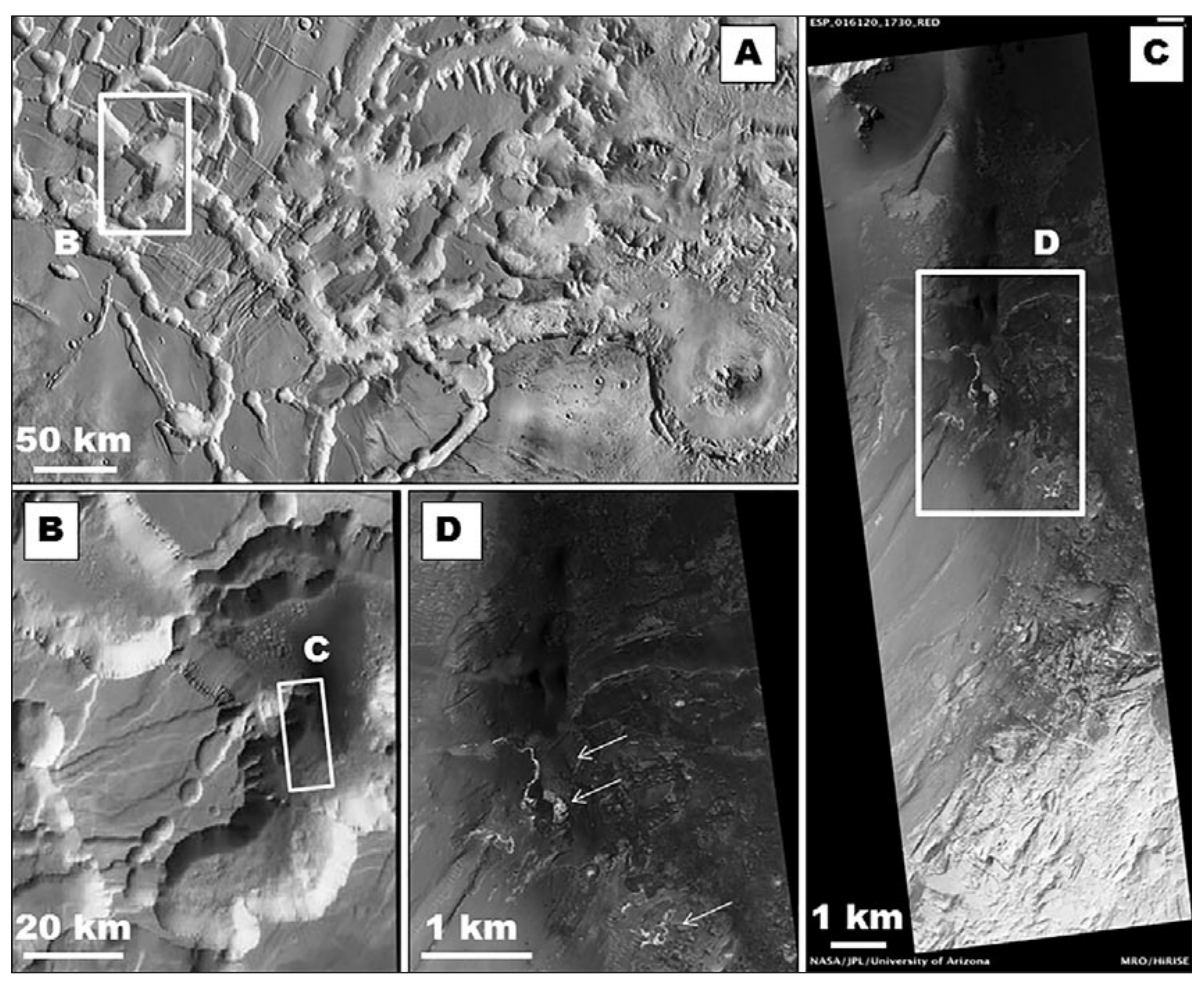

Fig. 1: (A) Noctis Labyrinthus, Mars, with the location of the trough object of the study (white box) (image THEMIS daytime IR mosaic modified by Weitz et al. 2013, north toward up). (B) Image of the trough object of the study (Image modified HRSC ID:H3155_0000_ND3 taken from the website http://viewer. mars.asu.edu, north toward up) (C) Location of the study area (white box) within the trough in wester NL (Image M.R.O. HiRISE PSP_016120_1730, north toward up). (D) Image of the study area located in the central part of the trough with the location of the LTDs investigated (white arrows) (Image M.R.O. HiRISE PSP_016120_1730, north toward up). 


\section{STUDY AREA SETTING}

NL (Fig. 1A), on the eastern edge of the Tharsis Plateau, consists of a network of intersecting valleys that merge and coalesce with pit chains and larger troughs connecting the Tharsis volcanic rise and western Valles Marineris. This intricate system of Late Hesperian and Early Amazonian linear troughs and rounded pits (Tanaka \& Davis 1988; Tanaka et al. 2014) distributed in alignment to pre-existing faults and grabens oriented concentrically and radially to the elevated volcanic plains of Syria Planum, is unique in that it constitutes the only Valles Marineris boundary terrain thought to retain collapsed structures produced by groundwater flow-induced conduit formation (Tanaka \& Davis 1988), or alternatively, by the withdrawal of subsurface magmatic reservoirs (Mège et al. 2003). A very recent study (Rodrigues et al. 2016) showed that NL retains geologic evidence of conduit development associated with structurally-controlled groundwater flow through salt-rich upper crustal deposits, consistent with aquifer drainage from the Tharsis volcanic rise region.
The trough investigated in this paper (Fig. 1B), is located in the western part of NL, and it is centered at $6.81 \mathrm{~N}, 261.11 \mathrm{E}$ and is approximately $60 \mathrm{x} 50 \mathrm{~km}$ in dimension with a depth of $5 \mathrm{~km}$ below the adjacent plateau (Weitz et al. 2013). The trough floor is charaterised mainly by fissure vents and hummocky lava flows (Weitz \& Bishop 2011) with the age of these lava flows, that display a pyroxene-rich mineralogy, thought to be Late Amazonian (Mangold et al. 2010).

In the central region of the trough along the base of the wallrock (Fig. 1C-1D) several outcrops of relatively LTDs can be observed (Fig. 1D). These deposits have been interpreted as gypsum-bearing material from the mineralogical point of view (Weitz et al. 2013).

We focused our analysis on three LTDs (Figs. 1D$2 \mathrm{~A}-3 \mathrm{~A}-4 \mathrm{~A})$ that approximately have an area of $0.16 \mathrm{~km}^{2}$ (the southern LTD), $0.09 \mathrm{~km}^{2}$ (the central LTD) and 0.3 $\mathrm{km}^{2}$ (the northern LTD).

\section{METHODS}

Detailed morphologic and morphometric analyses of available images of the LTDs located within this trough were performed. Landform features were investigated through an integrated visual analysis of data from the MRO High-Resolution Imaging Science Experiment (HiRISE) (McEven et al. 2007) and the Context Camera (CTX) (Malin et al. 2007). Analysed CTX images (G03_019311_1728_XN_07S099W and G03_019522_1728_XN_07S099W) have a spatial resolution of $6 \mathrm{~m} /$ pixel. Analysed HiRISE images (ESP_017043_1730 and PSP_016120_1730_) have a spatial resolution ranging 26 to $27 \mathrm{~cm}$ per pixel (objects of $78-79 \mathrm{~cm}$ across were resolved). HiRISE images, including enhanced RGB, IRB and derived stereoanaglyph im- ages, gave sufficient detail to observe small characteristics of the landforms. Additionally, a digital terrain model of the study area was built by using two HiRISE stereoimages (ESP_017043_1730 and PSP_016120_1730) and photostereogrammetry software (NASA AMES Stereo Pipeline v. 2.4.0), with height calibration referenced over MOLA data (Broxton \& Edwards 2008). The model has a spatial resolution of $1 \mathrm{~m} /$ pixel, which is sufficient for the landforms to be recognised in 3D by the GIS software misuration tool for detailed measurements of the studied depressions. Thus, the HiRISE images give sufficient detail to observe even small characteristics of the landforms.

\section{KARST LANDFORMS}

The analysis carried out revealed the presence of many shallow, rimless depressions of various sizes and shapes that are closed, surrounded entirely by unbroken plains.

The depressions are scattered and/or isolated (Figs. 2-3). Their locations and shapes appear to be un- related to the bedding plane, surface slope or tectonic lineaments (i.e. joints, faults). Their distribution seems random, with no particular pattern of orientation.

Depressions display various plan forms, ranging from rounded (Figs. 2B-2C) to circular (Figs. 2D-2E), 


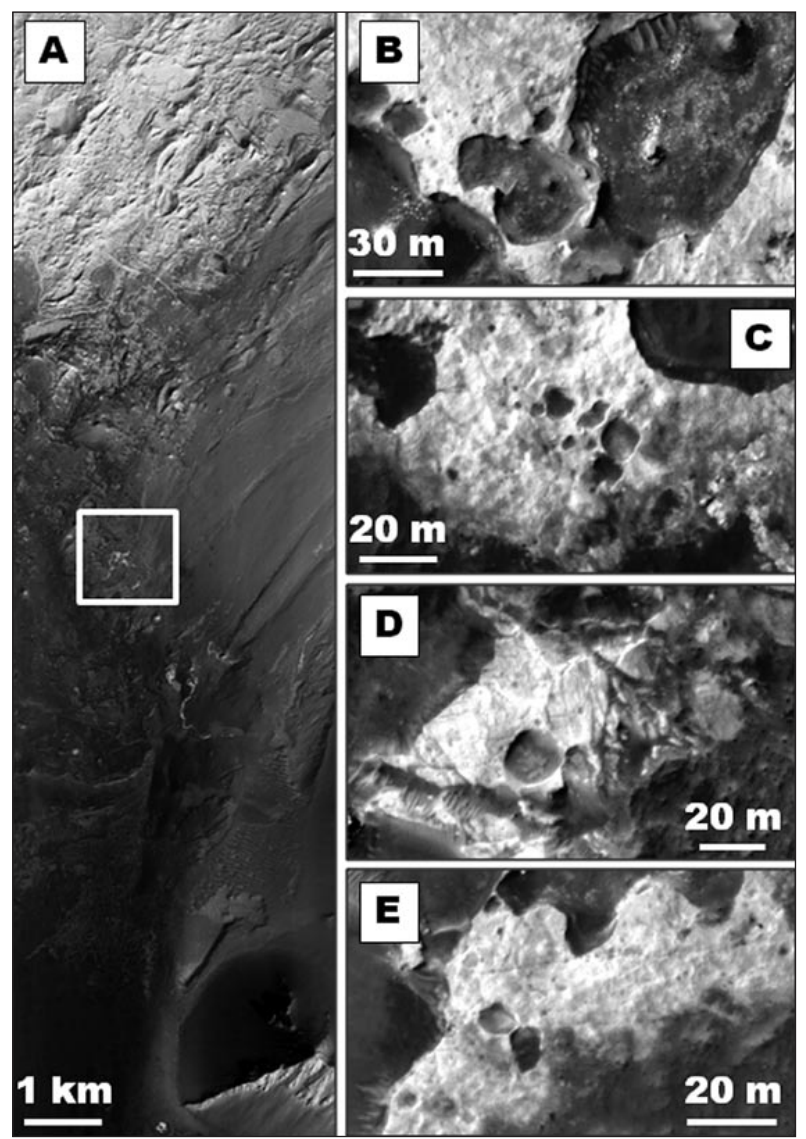

Fig. 2: Dolines in the southern LTD. (A) Location of the southern LTD displaying doline landforms on the floor of the trough (Image M.R.O. HiRISE ESP_017043_1730, north toward down). (B) Rounded dolines showing coalescence and a residual columnar structure in center (Image M.R.O. HiRISE PSP_016120_1730, north toward up) (C) Rounded dolines in the southern part of the LTD (Image M.R.O. HiRISE PSP_016120_1730, north toward up). (D) Circular doline in the northern part of the LTD (Image M.R.O. HiRISE PSP_016120_1730, north toward up) (E) Circular and rounded doline in the south-eastern part of the LTD (Image M.R.O. HiRISE PSP_016120_1730, north toward up).

drop-like (Fig. 3C) or elongated (Figs. 3B-3D). Some show coalescence with a rounded-elongate outline (Figs. 2A-2B-2C-3D).

The depressions range in length from about $10 \mathrm{~m}$ (Fig. 2C) to more than $90 \mathrm{~m}$ (Fig. 3D), while widths range from $5 \mathrm{~m}$ (Fig. 3B) to more than $50 \mathrm{~m}$ (Fig. 2B). The major axes have very different orientations, ranging from $\mathrm{N}-\mathrm{S}$ to $\mathrm{E}-\mathrm{W}$, from $\mathrm{NE}-\mathrm{SW}$ to $\mathrm{NW}-\mathrm{SE}$ and from ENE-WSW to NNW-SSE. Orientations are unrelated to depression locations and shapes.

The depressions display well-defined, continuous and sharp margins; their sides exhibit mainly symmetrical slopes, with very steep to almost vertical walls. The sides appear to lack slope processes and fan deposits at

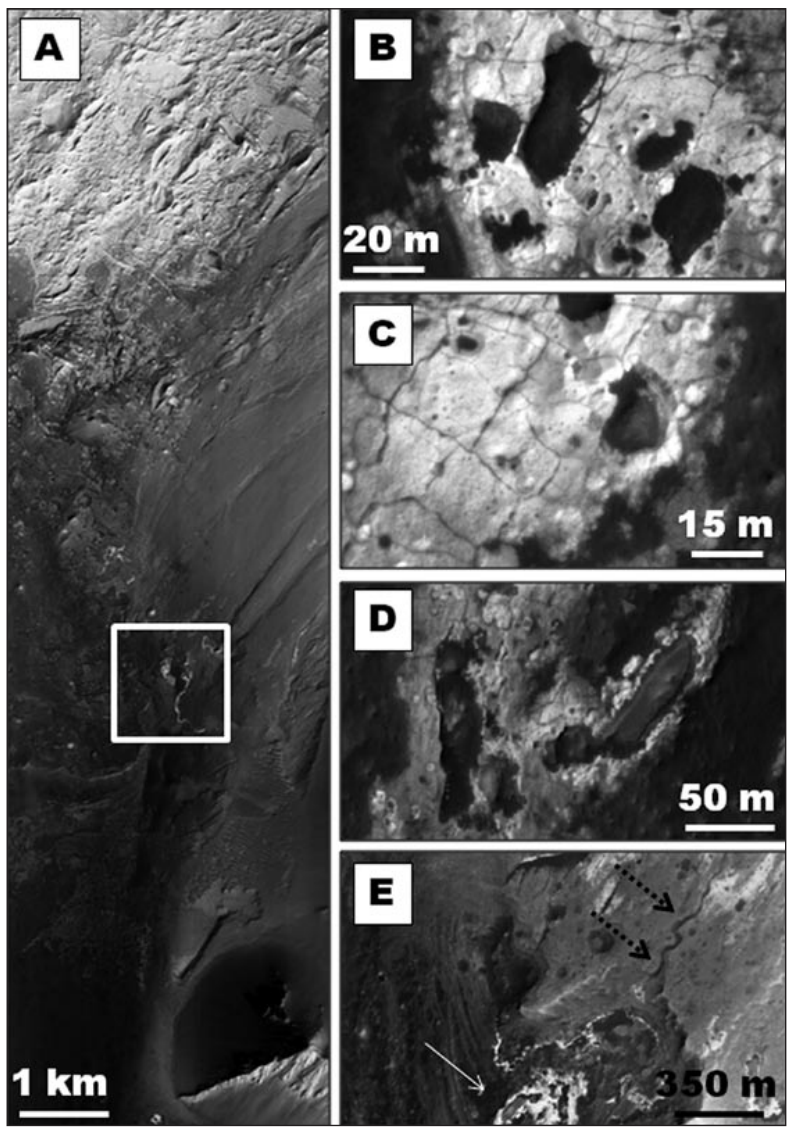

Fig. 3: Dolines in the central LTD. (A) Location of the southern LTD displaying doline landforms on the floor of the trough (Image M.R.O. HiRISE ESP_017043_1730, north toward down). (B) Elongate and irregular dolines in the southern part of the LTD (Image M.R.O. HiRISE PSP_016120_1730, north toward up). (C) Drop-like shaped doline located in the central part of the LTD (Image M.R.O. HiRISE PSP_016120_1730, north toward down). (D) Elongare doline in the southern part of the LTD (Image M.R.O. HiRISE PSP_016120_1730, north toward up). (E) Image of the LTD (white arrow) with the upper slope of the trough incised by a meandering channel (black arrows) (Image M.R.O. HiRISE PSP_017043_1730, north toward down).

the foot, and do not show stepped or terraced morphology.

The floors appear flat showing generally little dark or bright sediment and/or dust accumulation on the floors that lack well-developed systems of dune morphology.

In few cases in the center of the depressions a residual columnar structure can be observed. Here, the correlation between the bright upper rock unit located in the top of the columnar structure and in the surrounding landscape highlights the amount of erosive process that shaped the depression (Fig. 2B).

Polygonal-like karst (Williams 1972; White 1988; Ford \& Williams 2007) can be observed on the parts of 


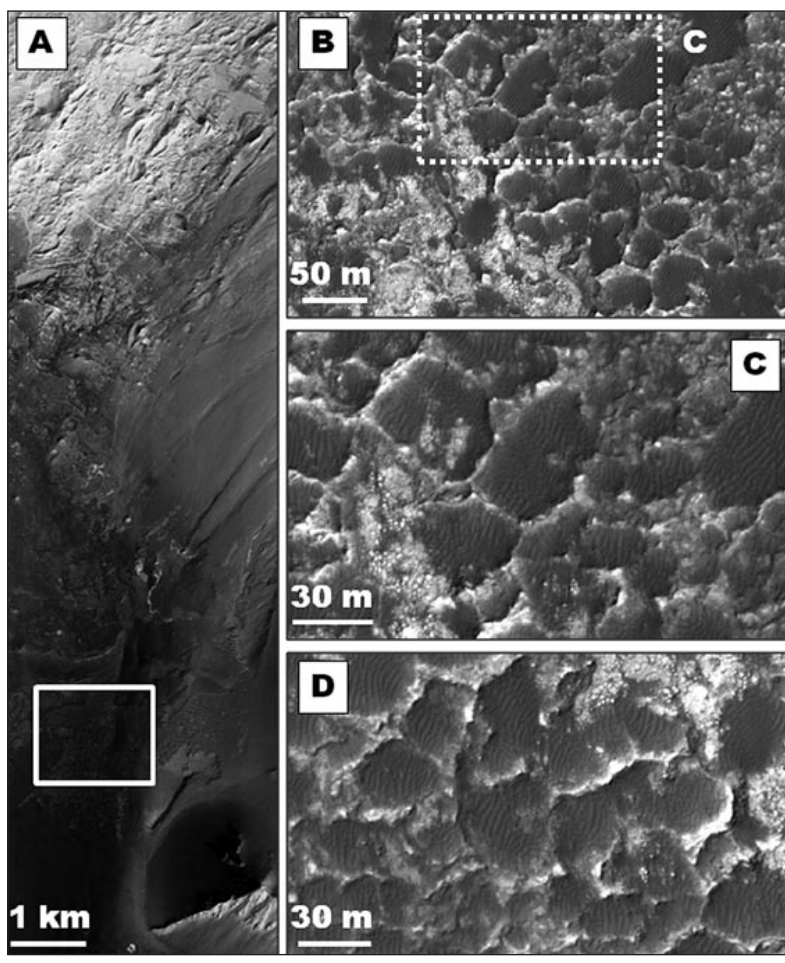

Fig. 4: Polygonal-like karst landscape in the northern LTD. (A) Location of the northern LTD displaying polygonal like karst area on the floor of the trough (Image M.R.O. HiRISE ESP_017043_1730) (north toward down). (B) Perspective view of polygonal like karst in the western part of the LTD (MRO HiRISE image ESP_017043_1730, north at the top of image). (C) Particular of the depressions displaying well defined shape with sharp divides (MRO HiRISE imageESP_017043_1730, north toward up). (D) Perspective view of polygonal-like karst in the eastern part of the LTD (MRO HiRISE image ESP_017043_1730, north at the top of image).

the trough floor that are completely flat (Fig. 4A). Here depressions entirely pock some parts of the surface and occupy most of its area (Fig. 4B). The depressions appear to be spaced farther apart, display well defined shapes with sharp divides (Figs. 4C-4D) and have diameters that range from $20 \mathrm{~m}$ to more than $80 \mathrm{~m}$. This area viewed from above, has an irregular "egg-box-like" topography and the divides between adjacent depressions form a cellular mesh pattern (Fig. 4B) just as typically happens in evaporite terrains on Earth where the inherently high solubility of evaporite rocks make densely-packed depressions (Warren 2006; Ford \& Williams 2007). Because of their rounded shape these can be interpreted as dolines of polygenetic origin (Williams 1972; White 1988; Ford \& Williams 2007). Because of the amount of sediment covering the bottom of the depressions we have no evidence that the water really penetrates into evaporitic rock, so they can also be formed like huge solution pans by standing or very slowly flowing water down from the trough walls.

Additionally, the main parameters used in the morphometric analysis of karst depressions on the Earth (Bondesan et al. 1992; Denizman 2003; Ford \& Williams 2007 ) such as the area (A), perimeter (P), elongation in$\operatorname{dex}(\mathrm{Ei})$, and circularity index $(\mathrm{Ci})$ were calculated.

The perimeter length $(\mathrm{P})$, calculated on the contour of the depressions, ranges from 24 to $\mathrm{m}$ to more than 220 $\mathrm{m}$, while the area $(\mathrm{A})$ of the depressions, calculated as the measurement of the planimetric surface bordered by the perimeter, ranges from $40 \mathrm{~m}^{2}$ to more than 2,000 $\mathrm{m}^{2}$.

The elongation index, expressed as the ratio between the longest axis and the perpendicular width $(\mathrm{L} / \mathrm{W})$, was calculated. The depressions have very different elongation index values. Rounded and circular shapes have values which range from 1.03 to 2.64 , while the values for elongated shapes range from 3.62 to more than 4.38 . Finally, the circularity index (ratio between the measured depression area and the area of a circle with the same perimeter) range between 0.99 and 0.27 .

\section{DISCUSSION}

\section{INTERPRETATION OF THE ORIGIN OF THE DEPRESSIONS}

Based on a detailed analysis of the characteristics of the features described above, we interpreted these morphologies as karst depressions. The features demonstrate major contributions of karst processes, because they lack evidence of wind action or erosional features associated with the evolution of impact craters.

In particular, these depressions were not formed by wind deflation, mainly because they lack a dominant ori- entation (major axes show different orientation peaks). Depressions shaped by wind action on the Earth, called blowouts (bowl-shaped hollows or slight depressions caused by deflation) (Neuendorf et al. 2005), are very elongated along the wind-flow direction. They have very elliptical shapes, arcuate sides and thicker sediment accumulations at the foot of the wind-facing wall. Depressions in NL do not display any of these features.

Moreover, features of the depressions do not support their formation as eroded or softened impact 
craters, as indicated by two lines of evidence. Firstly, the depressions display various plan forms, such as lobate, elongate, drop-like and polygonal, that cannot be shaped by an impact, which would instead create bowlshaped depressions characterised by a circular plan form (De Pablo \& Komatsu 2009). Secondly, all of the observed depressions lack raised rims and ejecta. It is unlikely that all possible rims and ejecta deposits were totally destroyed or cancelled by erosion processes. Several authors have investigated changes in Martian crater morphology through the advanced stage of modification due to erosion processes (Craddock et al. 1997; Forsberg-Taylor et al. 2004). When rims are removed completely due to erosion and back-wasting processes, the crater fills with a deposit having a generally parabolic or super-parabolic cross-section (Forsberg-Taylor et al. 2004), and the crater walls show a decrease of the average interior slope (Craddock et al. 1997). In contrast, the depressions observed here do not display these features and instead have smaller, flat floors and steep or vertical walls.

The thermokarst origin can be ruled out in this study due to the absence of other morphologies on the floor of the depressions, suggesting ice sublimation such as unsorted polygons.

The landforms display morphological convergence with terrestrial dolines and their formation process is analogous to the development of similar landforms in evaporite rock on Earth, where the presence of dolines, as a karst landform index (Ford \& Williams 2007), indicates intense surface dissolution and runoff along the whole area. The landforms have morphometric (size) and morphologic (shape) similarities with terrestrial dolines (Tab. 1) that commonly develop in all kinds evaporite terrains described in several regions on Earth (Johnson 1997; Ford 1998; Ferrarese et al. 2002; Cucchi \& Zini 2003; Gutierrez et al. 2008; Galve et al. 2009; Di Maggio et al. 2012). Additionally, they strongly resemble the evaporite dolines described in other regions of Mars (Tab. 1), such as Tithonium Chasma (Baioni \& Wezel 2008; Baioni et al. 2009; Baioni \& Wezel 2010; Baioni 2013), Coprates Chasma (Baioni et al. 2011), Hebes Chasma (Grindrod \& Balme 2010; Jackson et al. 2011), Sinus Meridiani (Baioni \& Sgavetti 2013; Flahaut et al. 2015), Iani Chaos (Baioni \& Tramontana 2015) and other regions (Schaeffer 1990; Spencer \& Fanale 1990; McKey \& Nedell 1998).

\section{MORPHOGENESIS OF KARST LANDFORMS}

The landform features appear to reflect ice- and/or waterrelated processes. In our opinion, the landforms provide compelling evidence of the existence of liquid water. The development of landforms related to liquid water on
Mars could have been triggered by the melting of ice and/ or snow, and/or permafrost, or alternatively by the structural delivery of water to the surface. The study area lacks morphological features and topography that would suggest the presence of sapping processes due to structural control. Therefore, the melting of ice or snow could have driven the processes of dissolution or collapse on the evaporite rock, as it happens on ice-covered terrain on the Earth. The melting of ice or snow provides the water necessary for the dissolution and collapse processes, as inferred to explain the karst landforms and topography found in other regions of Mars, such as Sinus Meridiani (Baioni \& Sgavetti 2013; Flahaut et al. 2015), Tithonium Chasma (Baioni 2013; Wezel \& Baioni 2010), Coprates Chasma (Baioni et al. 2011), Hebes Casma (Grindrod \& Balme 2010; Jackson et al. 2011) and Tyrrhena Terra (Baioni \& Tramontana 2016), as well as in karst terrains of Canada, the United States, Russia and the high mountain regions of Europe.

The necessary liquid water for the solutional processes observed has been provided by melting ice or snow, which on steeper slopes of the trough can be canalized toward the bottom. The melting of ice or snow, which can be formed during periods of ice-snowrich deposition from the atmosphere that may occur as the result of changes in the obliquity of Mars (Mustard et al. 2001; Laskar et al. 2004; Pacifici et al. 2009). In fact, theoretical considerations about the stability of water ice and numerical simulations of climate predict that surface ice accumulation areas may have shifted repeatedly between polar, middle, tropical and equatorial latitudes in the past, in response to changes in Martian orbital and atmospheric characteristics (Forget et al. 2006; Madeleine et al. 2009; Wordsworth et al. 2013). Some simulations predict that net ice accumulation rates might have been higher than $20 \mathrm{~mm} /$ year in locations along the Martian equator. Such shifts may have been necessary to achieve the Amazonian physical conditions, based on the present day composition of the atmosphere (Madeleine et al. 2009), and other physical conditions in the past (Wordsworth et al. 2013). The ice and/or snow melting probably occurred gradually rather than rapidly, and had to persist long enough to shape the karst landforms observed. The landforms observed allow us to establish that the source of the water might be the melting of ice or snow rather than other different processes such us, rain or atmospheric humidity. In particular, on the down slope part of the trough wall, the presence of several meandering channels (Fig. 3E) provide compelling evidence of the presence of liquid water probably due to melting of ice or snow as the main processes involved in their formation and shaping. 


\section{CONCLUSIONS}

The analysis carried out in this study suggests that:

i) On the basis of the characteristics of the investigated landforms and the similarities of features on Earth and Mars, and after discarding other possible origins, we interpret the landforms NL to be karst landforms.

ii) karst landform characteristics and erosional ages on Mars highlight a young erosional age and suggest that the landforms were affected by a single geologic "wet episode", characterised by a period of sufficient water availability caused by the melting of ice, followed by dry climate conditions.

iii) The karst landforms suggest a response to climatologic change, requiring the presence of sufficient water for their development. Environmental conditions on Mars were very different in the past than they are today. Climatic change occurred in the equatorial and tropical regions, confirming the presence of water at this latitude, probably during the late Amazonian period.

\section{REFERENCES}

Baioni, D. \& F.C. Wezel, 2008: Similarities of a martian dome with terrestrial salt domes.- Italian Journal of Geosciences, 127, 3, 453-465.

Baioni, D., Zupan Hajna, N. \& F.C. Wezel, 2009: Karst landforms in a martian evaporitic dome.- Acta Carsologica, 38, 1, 9-18. DOI: http://dx.doi. org/10.3986/ac.v38i1.132.

Baioni D, \& F.C. Wezel, 2010: Morphology and origin of an evaporitic dome in the eastern Tithonium Chasma, Mars.- Planetary and Space Science, 58, 847-857. DOI: http://dx.doi.org/10.1016/j. pss.2010.01.009.

Baioni, D., Zupan Hajna, N. \& F.C. Wezel, 2011: Karst landforms in an interior layered deposit within the Coprates chasma, Mars.- Acta Carsologica 40, 3, 473-481. DOI: http://dx.doi.org/10.3986/ ac.v40i3.59.

Baioni, D., 2013: Morphology and geology of an interior layered deposit in the western Tithonium Chasma, Mars.- Planetary and Space Science, 89, 140-150. DOI: http://dx.doi.org/10.1016/j.pss.2013.09.019.

Baioni, D. \& M. Sgavetti, 2013: Karst terrains as possible lithologic and stratigraphic markers in northern Sinus Meridiani, Mars.- Planetary and Space Science, 75, 173-181. DOI: http://dx.doi.org/10.1016/j. pss.2012.08.011.

Baioni, D. \& M. Tramontana, 2015: Evaporite karst in three interior layered deposits in Iani Chaos, Mars. Geomorphology, 245, 15-22. DOI: http://dx.doi. org/10.1016/j.geomorph.2015.05.018.

Baioni, D. \& M. Tramontana, 2016: Possible karst landforms in two unnamed craters in Tyrrhena Terra, Mars.- Planetary and Space Science, 132, 57-65. DOI: http://dx.doi.org/10.1016/j.pss.2016.08.011.
Bibring, J.P., Langevin, Y., Mustard, J.F., Poulet, F., Arvidson, R., Gendrin, A., Gondet, B., Mangold, N., Pinet, P., Forget, F., \& the OMEGA team, 2006: Global Mineralogical and Aqueous Mars History Derived from OMEGA/Mars Express Data.- Science, 312, 400-404. DOI: http://dx.doi.org/10.1126/science. 1122659 .

Bondesan, A., Meneghel, M. \& U. Sauro, 1992: Morphometric analysis of doline.- International Journal of Speleology, 21, 1-55. DOI: http://dx.doi. org/10.5038/1827-806X.21.1.1.

Boston, P., 2004: Extraterrestrial caves, in: Gunn, J., (Ed.), Encyclopedia of caves and karst science. Fitzroy Dearborn, New York, London, pp. 355-357.

Brinkmann, R., Parise, M. \& D. Dye, 2008: Sinkhole distribution in a rapidly developing urban environment: Hillsborough County, Tampa Bay area, Florida.- Engineering Geology, 99, 169-184. DOI: http:// dx.doi.org/10.1016/j.enggeo.2007.11.020.

Broxton, M.J. \& M. L.J. Edwards, 2008: The Ames Stereo Pipeline: Automated 3D Surface Reconstruction from Orbital Imagery.- $39^{\text {th }}$ Lunar and Planetary Science Conference, $10^{\text {th }}-14^{\text {th }}$ March 2008, League City, Texas, 2414, Texas.

Costard, F.M. \& J.S. Kargel, 1995: Outwash plains and thermokarst on Mars.- Icarus, 114, 93-112. DOI: https://doi.org/10.1006/icar.1995.1046.

Craddock, R.A., Maxwell, T.A. \& A.D. Howard, 1997: Crater morphometry and modification in the Sinus Sabaeus and Margaritifer Sinus region of Mars.Journal of Geophysical Research 102, E6, 1332113340. DOI: http://dx.doi.org/10.1029/97JE01084

Cucchi, F. \& L. Zini, 2003: Gypsum karst of Zagros mountains (I.R. Iran).- Acta Carsologica, 32, 1, 6982. DOI: http://dx.doi.org/10.3986/ac.v32i1.365. 
Denizman, C., 2003: Morphometric and spatial distribution parmeters of karstic depressions, Lower Suwannee River Basin, Florida.- Journal of Cave and Karst Studies, 65, 1, 29-35.

De Pablo, M.A. \& G. Komatsu, 2009: Possible pingo fields in the Utopia basin, Mars: Geological and climatical implications.- Icarus, 199, 49-74. DOI: http:// dx.doi.org/10.1016/j.icarus.2008.09.007.

Di Maggio, C., Madonia, G., Parise, M. \& M. Vattano, 2012: Karst of Sicily and its conservation.-Journal of Cave and Karst Studies, 74, 22, 157-172. DOI: http://dx.doi.org/10.4311/2011JCKS0209.

Ferrarese, F., Macaluso, T., Madonia, G., Palmeri, A., \& U. Sauro 2002: Solution and recrystallisation processes and associated landforms in gypsum outcrops of Sicily.- Geomorphology, 49, 25-43. DOI: http://dx.doi.org/10.1016/S0169-555X(02)00159-9.

Flahaut, J., Carter, J., Poulet, F., Bibring, J.-P., van Westrenen, W., Davies, G.R. \& S.L Murchie, 2015: Embedded clays and sulfates in Meridiani Planum, Mars.- Icarus, 248, 269-288. DOI: http://dx.doi. org/10.1016/j.icarus.2014.10.046.

Ford, D.C., 1998: Principal features of evaporite karst in Canada.- Geografia Fisica e Dinamica Quaternaria, 3, 11-19.

Ford, D.C. \& P.W. Williams, 2007: Karst Hydrogeology and Geomorphology.- Wiley \& Sons Ltd, pp. 562, West Sussex.

Forget, F., Haberle, R.M., Montmessin, F., Levrard, B. \& J.W. Head, 2006: Formation of glaciers on Mars by atmospheric precipitation at high obliquity.Science, 311, 5759, 368-371. DOI: http://dx.doi. org/10.1126/science.1120335.

Forsberg-Taylor, N.K., Howard, A.D. \& R.A. Craddock, 2004: Crater degradation in the Martian highlands: Morphometric analysis of the Sinus Sabaeus region and simulation modeling suggest fluvial processes.Journal of Geophysical Research, 109, E05002. DOI: http://dx.doi.org/10.1029/2004JE002242

Galve, J.P., Gutiérrez, F., Lucha, P., Bonachea, J., Cendrero, A., Gimeno, M.J., Gutiérrez, M.,Pardo, G.,Remondo, J. \& J.A. Sánchez, 2009: Sinkholes in the salt-bearing evaporate karst of the Ebro River valley upstream of Zaragoza city NE Spain. Geomorphological mapping and analysis as a basis for risk management.Geomorphology, 108, 145-158. DOI: http://dx.doi. org/10.1016/j.geomorph.2008.12.018.

Grindrod, P.M. \& M.R. Balme, 2010: Groundwater processes in Hebes Chasma, Mars.- Geophysical Research Letters, 37, L13202. DOI: http://dx.doi. org/10.1029/2010GL044122
Guest, J.E., Butterwhorth, P.S. \& R. Greeley, 1977: Geologic observation in the Cydonia region of Mars.Journal of Geophysical Research, 82, 4111-4120. DOI: http://dx.doi.org/10.1029/JS082i028p04111.

Gutiérrez, F., Johnson, K. \& A. Cooper, 2008: Evaporite karst processes, landforms, and environmental problems.- Environmental Geology, 53, 5, 935-936. DOI: http://dx.doi.org/10.1007/s00254-007-0715-9.

Jackson, M.P.A., Adams, J.B., Dooley, A.R. \& D.R. Montgomery, 2011: Modeling the collapse of Hebes Chasma, Valles Marineris, Mars.- GSA Bulletin, 123, 7-8, 1596-1627. DOI: http://dx.doi.org/101130/ B30307.1.

Johnson, K.S., 1997: Evaporite karst in the United States.Carbonates and Evaporites, 12, 1, 2-14. DOI: http:// dx.doi.org/10.1007/BF03175797.

Johnston, J.G., Boston, P.J., \& K.W. Stafford, 2006. Assessment of karst landform potential on Mars.- $37^{\text {th }}$ Lunar and Planetary Science Conference, $13^{\text {rd }}-17^{\text {th }}$ March 2006, League City, Texas, 1980, Texas.

Kargel, J.S., Dougherty, A., Feldman, W., Hogenboom, D., Marion, G., McCarthy, C. \& O. PrietoBallesteros, 2004: Hydrated Salts: Dehydration, dissolution, and incongruent melting in terrestrial evaporites and at Meridiani Planum, Mars.- American Geophysical Union, Fall Meeting 2004, $13^{\text {rd }}-17^{\text {th }}$ December 2004, San Francisco, P21A-0205, San Francisco.

Keskim, I. \& I. Yilmaz, 2016: Morphometric and geological features of karstic depressions in gypsum (Sivas, Turkey).- Environmental Earth Sciences, 75, 1040. DOI: http://dx.doi.org/10.1007/s12665-0165845-5.

Laskar, J., Correia, A.C.M., Gastineau, M., Joutel, F., Levrard, B. \& P. Robutel, 2004: Long term evolution and chaotic diffusion of the insolation quantities of Mars.- Icarus, 170, 343-364. DOI: http://dx.doi. org/10.1016/j.icarus.2004.04.005.

Madeleine, J.B., Forget, F., Head, J.W., Levrard, B., Montmessin, F. \& E. Millaur, 2004: Amazonian northern mid-latitude glaciation on Mars: A proposed climate scenario.- Icarus, 203, 390-405. DOI: http:// dx.doi.org/10.1016/j.icarus.2009.04.037.

Malin, M.C., Bell III, J.F., Cantor, B.A., Caplinger, M.A., Calvin, W.M., Clancy, R.T., Edgett, K.S., Edwards, L., Haberle, R.M., James, P.B., Lee, S.W., Ravine, M.A., Thomas, P.C. \& M.L. Wolff, 2007: Context Camera Investigation on board the Mars Reconnaissance Orbiter.- Journal of Geophysical Research, 112, E05S04. DOI: http://dx.doi. org/10.1029/2006JE002808. 
Mangold, N., Roach, L., Milliken, R., Le Mouélic, S., Ansan, V., Bibring, J.P., Masson, Mustard, J.F., Murchie, S. \& G. Neukum, 2010: A Late Amazonian alteration layer related to local volcanism on Mars.- Icarus, 207, 265-276. DOI: http://dx.doi.org/10.1016/j. icarus.2009.10.015.

McEven, A.S., Eliason, E.M., Bergstrom, J.W., Bridges, N.T., Hansen, C.J., Delamere, W.A., Grant, J.A., Gulick, V.C., Herkenhoff, K.E., Keszthelyi, L., Kirk, R.L., Mellon, M.T., Squyres, S.W., Thomas, N. \& C.M. Weitz, 2007: Mars reconnaissance Orbiter's High Resolution Imaging Science Experiment (HiRISE).Journal of Geophysical Research, 112, E05S02. DOI: http://dx.doi.org/10.1029/2005JE002605.

McKay, C.P. \& S.S. Nedell, 1988: Are there carbonate deposits in Valles Marineris, Mars?.- Icarus, 73, 142148. DOI: http://dx.doi.org/10.1016/0019-1035(88)90088-7.

Mège, D., Cook, A.C., Garel, E., Lagabrielle, Y. \& M. Cormier, 2003: Volcanic rifting at Martian grabens.- Journal of Geophysical Research, 108, 5044. DOI:http://dx.doi.org/10.1029/2002JE001852.

Murchie, S., Arvidson, R., Bedini, P., Beisser, K., Bibring, J.-P., Bishop, J., Boldt, J., Cavender, P., Choo, T., Clancy, R.T., Darlington, E.H., Des Marais, D., Espiritu, R., Fort, D., Green, R., Guinness, E., Hayes, J., Hash, C., Heffernan, K., Hemmler, J., Heyler, G., Humm, D., Hutcheson, J., Izenberg, N., Lee, R., Lees, J., Lohr, D., Malaret, E., Martin, T., McGovern, J.A., McGuire, P., Morris, R., Mustard, J., Pelkey, S., Rhodes, E., Robinson, M., Roush, T., Schaefer, E., Seagrave, G., Seelos, F., Silverglate, P., Slavney, S., Smith, M., Shyong, W.-J., Strohbehn, K., Taylor, H., Thompson, P., Tossman, B., Wirzburger, M. \& M. Wolff, 2007: CRISM (Compact Reconnaissance Imaging Spectrometer for Mars) on MRO (Mars Reconnaissance Orbiter).- Journal of Geophysical Research, 112, E05S03. DOI: http://dx.doi. org/10.1029/2006JE002682.

Mustard, J.F., Cooper, C.D. \& M.K. Rifkin, 2001: Evidence for recent climate change on Mars from the identification of youthful near surface ground ice.- Nature, 412, 411-414. DOI: http://dx.doi. org/10.1038/35086515.

Neuendorf, K. K. E., Mehl J. P., \& J.A. Jackson, 2005: Glossary of Geology - American Geological Institute, pp.737 Alexandria, Virginia.

Pacifici, A., Komatsu, G., \& M. Pondrelli, 2009: Geological evolution of Ares Vallis on Mars: Formation by multiple events of catastrophic flooding, glacial and periglacial processes.- Icarus, 202, 1-60. DOI: http://dx.doi.org/10.1016/j.icarus.2009.02.029.
Rodriguez, J.A.P., Zarroca, M., Linares, R., Gulick, V., Weitz, C.M., Yan, J., Fairén, A.G., Miyamoto, H., Platz, T., Baker, V., Kargel, J., Glines, N. \& K. Higuchi, 2016: Groundwater flow induced collapse and flooding in Noctis Labyrinthus, Mars.- Planetary and Space Science, 124, 1-14. DOI: http://dx.doi. org/10.1016/j.pss.2015.12.009.

Schaeffer, M., 1990: Geochemical evolution of the northern plains of Mars: Early hydrosphere, carbonate development and present morphology.- Journal of Geophysical Research, 95(B9), 14291-14300. DOI: http://dx.doi.org/10.1029/JB095iB09p14291.

Spencer, J.R. \& F.P. Fanale, 1990: New models for the origin of Valles Marineris closed depressions.- Journal Geophysical Research, 95(B9), 14301-14313. DOI: http://dx.doi.org/10.1029/JB095iB09p14301.

Stafford, K.W. \& P.J. Boston, 2005: Theoretical evaporite karst development on Mars. $36^{\text {th }}$ Lunar and Planetary Science Conference, $14^{\text {th }}-18^{\text {th }}$ March 2005, League City, Texas, 2291 Texas.

Tanaka, K.L. \& P.A. Davis, 1988: Tectonic history of the Syria Planum Province of Mars.- Journal of Geophysical Research, 93, B12, 14893-14917. DOI: http://dx.doi.org/10.1029/JB093iB12p14893

Tanaka, K.L., Skinner, J.A., Dohm, J.M., Irwin, R.P., Kolb, E.J., Fortezzo, C.M., Platz, T., Michael, G.G. \& T.M. Hare, 2014: Geologic map of Mars: U.S. Geological Survey Scientific Investigation, Map 3292. 1:20,000,000. DOI: http://dx.doi.org./10.3133/ $\operatorname{sim} 3292 /$

Telbisz, T., Latos, T., Deak, M., Szekely, B., Koma, Z.\& T. Standovar, 2004: The advantage of lidar digital terrain models in doline morphometry compared to topographic map based dataset - Aggtelek karst (Hungary) as example.- Acta Carsologica, 45,1, 5-18. DOI: http://dx.doi.org/10.3986/ ac.v45i1.4138.

Warren, J.K., 2006: Evaporites: Sediments, Resources and Hydrocarbons.- Springer-Verlag, pp. 1036, New York.

Weiz, C.M. \& J.L. Bishop, 2011: A proposed future Mars landing site in Noctis Labyrinthus.- $39^{\text {th }}$ Lunar and Planetary Science Conference, $10^{\text {th }}-14^{\text {th }}$ March 2008, League City, Texas,1874, Texas.

Weiz, C.M., Bishop, J.L. \& J.A. Grant, 2013: Gypsum, opal and fluvial channels within a trough of Noctis Labyrinthus, Mars: Implications for aqueous activity during the late Hesperian to Amazonian.- Planetary and Space Science, 87, 130-145. DOI: http:// dx.doi.org/10.1016/j.pss.2013.08.007. 
Wezel, F.C. \& D. Baioni, 2010: Evidences for subaqueously resedimented sulphate evaporites on Mars.Planetary and Space Science, 58, 1500-1505. DOI: http://dx.doi.org/10.1016/j.pss.2010.07.003

White, W.B., 1988: Geomorphology and Hydrology of Karst Terrain. Oxford University Press, pp.464, New York.

Williams, P.W., 1972. Morphometric analysis of polygonal karst in New Guinea.- Geological Society of America Bulletin, 83, 761-796. DOI: http://dx.doi. org/10.1130/0016 7606(1972)83[761:MAOPKI].
Wordsworth, R., Forget, F.,Millour, E., Head, J.W.,Madeleine, J.-B. \& B. Charnay, 2013. Global modelling of the early Martian climate under a denser $\mathrm{CO}_{2}$ atmosphere: water cycle and ice evolution.- Icarus, 222, 1-19. DOI: http://doi. org/10.1016/j.icarus.2012.09.036. 